\title{
8. CRETACEOUS FORAMINIFERAL STRATIGRAPHY, DSDP LEG 33, HOLES 315A, 316, 317A
}

\author{
C.L. McNulty, ${ }^{1}$ The University of Texas at Arlington, Arlington, Texas
}

\section{INTRODUCTION}

Cretaceous rocks were drilled at three Sites during Leg 33, as listed below and shown in Figure 1. Hole $315 \mathrm{~A}$ was spudded at a point about 40 miles eastnortheast of Fanning Island in the central portion of the Line Islands chain. Site 316 was chosen on the west side of the chain, near its southern end. Hole $317 \mathrm{~A}$ is located in the central portion of the Manihiki Plateau, about 80 miles southwest of Manihiki Island.

\begin{tabular}{|c|c|c|c|}
\hline Hole & General Location & Latitude & Longitude \\
\hline $315 \mathrm{~A}$ & $\begin{array}{l}\text { Central Line Islands } \\
\text { chain }\end{array}$ & $4^{\circ} 10.26^{\prime} \mathrm{N}$ & $158^{\circ} 31.54^{\prime} \mathrm{W}$ \\
\hline 316 & $\begin{array}{l}\text { Southern Line Islands } \\
\text { chain }\end{array}$ & $0^{\circ} 05.44^{\prime} \mathrm{N}$ & $157^{\circ} 07.71^{\prime} \mathrm{W}$ \\
\hline $317 \mathrm{~A}$ & $\begin{array}{l}\text { Central Manihiki } \\
\text { Plateau }\end{array}$ & $11^{\circ} 00.09^{\prime} \mathrm{S}$ & $162^{\circ} 15.78^{\prime} \mathrm{W}$ \\
\hline
\end{tabular}

The first two sites were chosen to provide a thick record of sediments from the Line Islands and coastal waters. The Cretaceous succession is generally turbiditic and/or volcanogenic, of which the latter aspect becomes conspicuous below the upper Campanian in both locations.

The third site was chosen to obtain information on the relatively thick, pelagic section over a very prominent feature, the Manihiki Plateau. Although the basal 250 meters of the succession is highly volcanogenic, the overlying 100 meters of Cretaceous is pelagic and quite different from the successions of Hole 315A and Site 316. Foraminiferal faunas vary sharply with lithology, which includes a thin, uppermost, Cretaceous chalk, underlying dark clays and clayey chalks, and AptianAlbian carbonates overlying the basal volcanogenic section.

Relatively few of the Cretaceous planktonic foraminiferal zones could be recognized. Those proposed for the Upper Cretaceous follow the definitions of Cita and Gartner (1971) and those for the Lower Cretaceous follow van Hinte (1971).

\section{QUALITY OF DATA}

The recovery of foraminifers from samples was very poor, as indicated by the fact that only 54 of 193 samples yielded usable material. As a consequence of these poor recoveries, faunal intervals and zonal identifications are based upon very few samples in most cases. Accordingly, faunas will be presented in text only, except for the Aptian-Albian. Recoveries from this succession are

'Present address: Dept. of Geology, University of Papua, P.O. Box 4820, University, Papua, New Guinea. somewhat better; the information is more important and is presented in a distribution chart (Table 1).

\section{TREATMENT OF SAMPLES}

Treatment with petroleum ether (paint thinner, dry cleaning fluid, etc.) was found more effective than any other method. Samples were crushed if indurated, heated to some degree of cracking from desiccation, and immersed in petroleum ether for $24 \mathrm{hr}$, if time was available. Then the ether was decanted and samples were immersed in water, preferably distilled. Ideally disaggregation begins immediately upon water immersion and can be readily observed. If disaggregation is incomplete after $24 \mathrm{hr}$ of immersion in water, the sample should be decanted, dried, and treated again. Adequate heating and drying appears to be quite important.

Residues were washed on a No. 200 screen and were picked in conventional manner; faunal slides were prepared in all cases.

\section{FAUNAL INTERVALS}

\section{Line Islands Chain}

\section{Hole 315A}

Interval of Core 18 to $19-2,29-30 \mathrm{~cm}(806.5-817.9 \mathrm{~m})$

Correlation: Maestrichtian

Contributory Samples: 19-1, 139-140 cm; 19-2, 29-30 $\mathrm{cm}$

Fauna: Planktonics

Globotruncana aegyptiaca Nakkady, G. arca (Cushman), G. elevata (Brotzen), G. falsostuarti Sigal, G. fornicata Plummer, G. lapparenti Brotzen, $G$. rosetta (Carsey)?, $G$. stuartiformis Dalbiez, Pseudoguembelina costulata (Cushman).

Fauna: Benthonics

Clavulinoides asper (Cushman), Gaudryina pyramidata Cushman, Marssonella sp., Nuttallides florealis (White), N. texana (Cushman), ?Oridorsalis umbonatus (Reuss), Rotorbinella supracretacea (Schijfsma).

Because of abundant chert, core recovery for the interval from the top of Core 10 through Core 17 was poor and no foraminiferal samples were available. Recovery was good for Core 18, but none of the five samples yielded adequate foraminifers in residues despite the evident presence of abundant, recrystallized specimens in untreated cores. However, nannofossil data indicates Cretaceous species in Cores 16, 17, and 18, and this information is employed in selecting the top of the foraminiferal Maestrichtian.

The planktonics of this fauna were derived from one sample, 19-2, 29-30 cm. They suggest a $G$. arca-G. gansseri boundary shortly above, but this cannot be verified from residues of beds above and below this sample. 


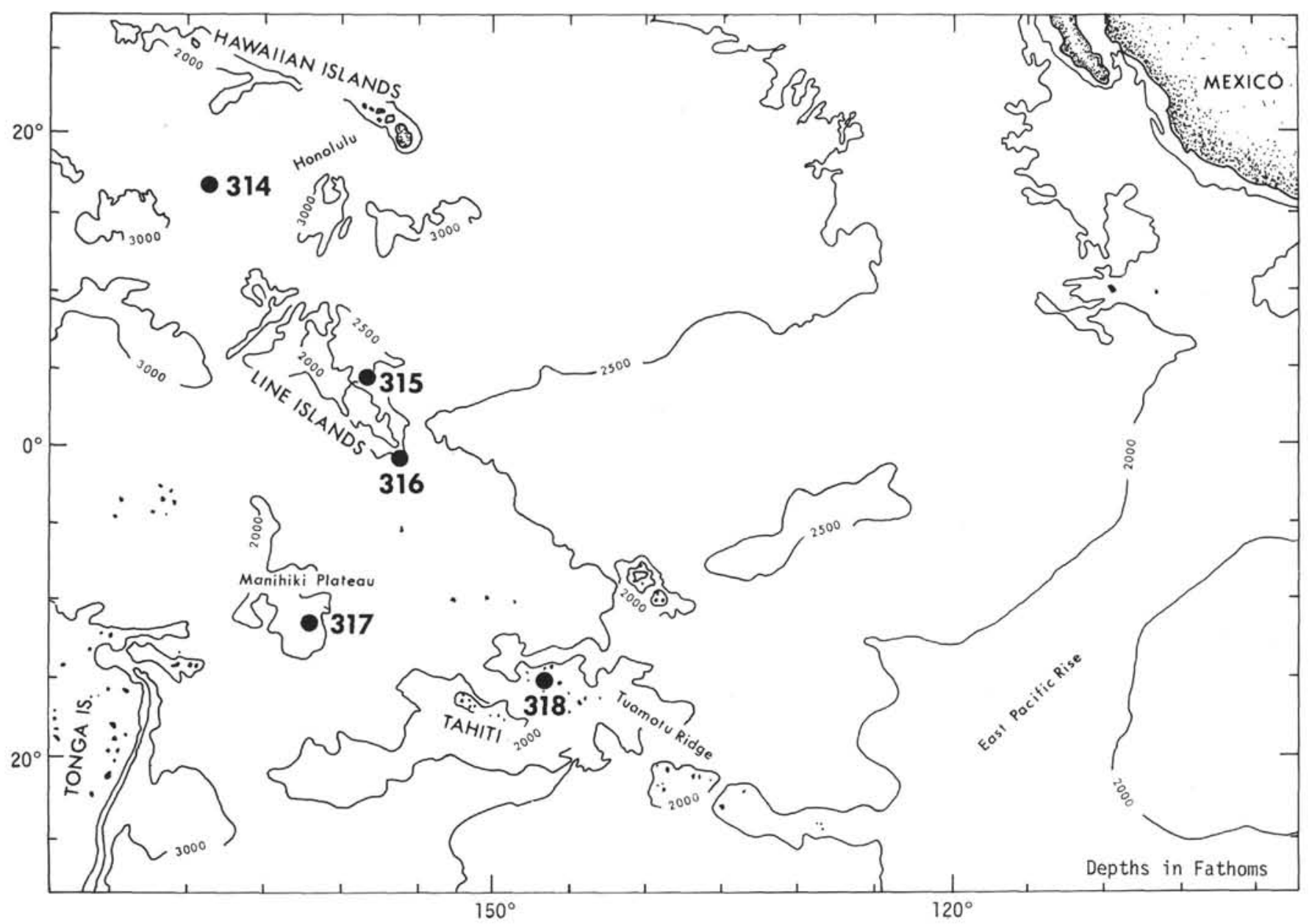

Figure 1. Location of sites drilled during Deep Sea Drilling Project Leg 33.

In addition to the benthonics listed above, residues contain many large, poorly preserved and unidentifiable discorbids and other rotaliiforms. Reefal larger foraminifers, which are discussed by Beckmann (this volume), were observed in thin sections and untreated cores (17-2, 117-119 $\mathrm{cm}$ and 18-2, 89-91 cm).

Interval of $19-3,38-40 \mathrm{~cm}$ through $21-5,119-120 \mathrm{~cm}$ (819.38-842.7 m)

Correlation: Upper Campanian, Globotruncana calcarata Zone

Contributory Samples: 19-3, 38-40 cm; 19-5, 140-142 $\mathrm{cm} ; 21-3,5-7 \mathrm{~cm} ; 21-5,119-120 \mathrm{~cm}$

Fauna: Planktonics

Globotruncana arca (Cushman), G. calcarata Cushman, G. elevata (Brotzen), G. fornicata Plummer, G. lapparenti Brotzen, G. linneiana (d'Orbigny), G. stuartiformis Dalbiez, G. ventricosa White, Heterohelix pulchra (Brotzen), H. punctulata (Cushman), H. striata (Ehrenberg), Planoglobulina multicamerata de Klasz, Pseudoguembelina costulata (Cushman), Pseudotextularia elegans (Rzehak).

Fauna: Benthonics

Aragonia trinitatensis (Cushman and Jarvis), Bulimina reussi Morrow, Dorothia trochoides (Marsson), Ellipsodimorphina subcompacta Liebus, Ellipsoglandulina velascoensis Cushman, Gaudryina pyramidata Cushman, Gyroidina globosa (Hagenow), Pleurostomella subnodosa
Reuss, Reussella szajnochae (Grzybowski), Semivulvulina dentata (Alth), Spiroplectammina spectabilis (Grzybowski), Stensioina excolata (Cushman), Textularia ripleyensis W. Berry, Vulvulina spinosa Cushman.

This is a total-range zone and was confined to limits of appearance $(21-5,120 \mathrm{~cm})$ and extinction (19-3, 38 $\mathrm{cm}$ ) of the nominate species, which is relatively common and persistent in samples of the zone.

Evidently the Campanian-Maestrichtian boundary lies between 19-3, 38-40 cm and 19-2, 29-30 cm, or at about 818 meters.

Interval of $21-5,119-120 \mathrm{~cm}$ to basalt $(842.7-996 \mathrm{~m})$

Correlation: Lower Campanian, Globotruncana elevata Zone

Contributory Samples: $23-3,0-2 \mathrm{~cm} ; 24-3,16-18 \mathrm{~cm}$

Fauna: Planktonics

Archaeoglobigerina blowi Pessagno, Globigerinelloides asper (Ehrenberg), Globotruncana fornicata Plummer, G. stuartiformis Dalbiez, G. lapparenti Brotzen.

Fauna: Benthonics

Aragonia trinitatensis (Cushman and Jarvis), Dentalina megalopolitana Reuss, Dorothia trochoides (Marsson), Gaudryina pyramidata Cushman, Gyroidina globosa (Hagenow), Nodosarella gracillima Cushman, Nuttalides texana (Cushman), Pleurostomella subnodosa Reuss, Pseudoclavulina amorpha Cushman, Reussela Szajnochae 
TABLE 1

Distribution of Selected Species, Lower Cretaceous, 317A, Manihiki Plateau

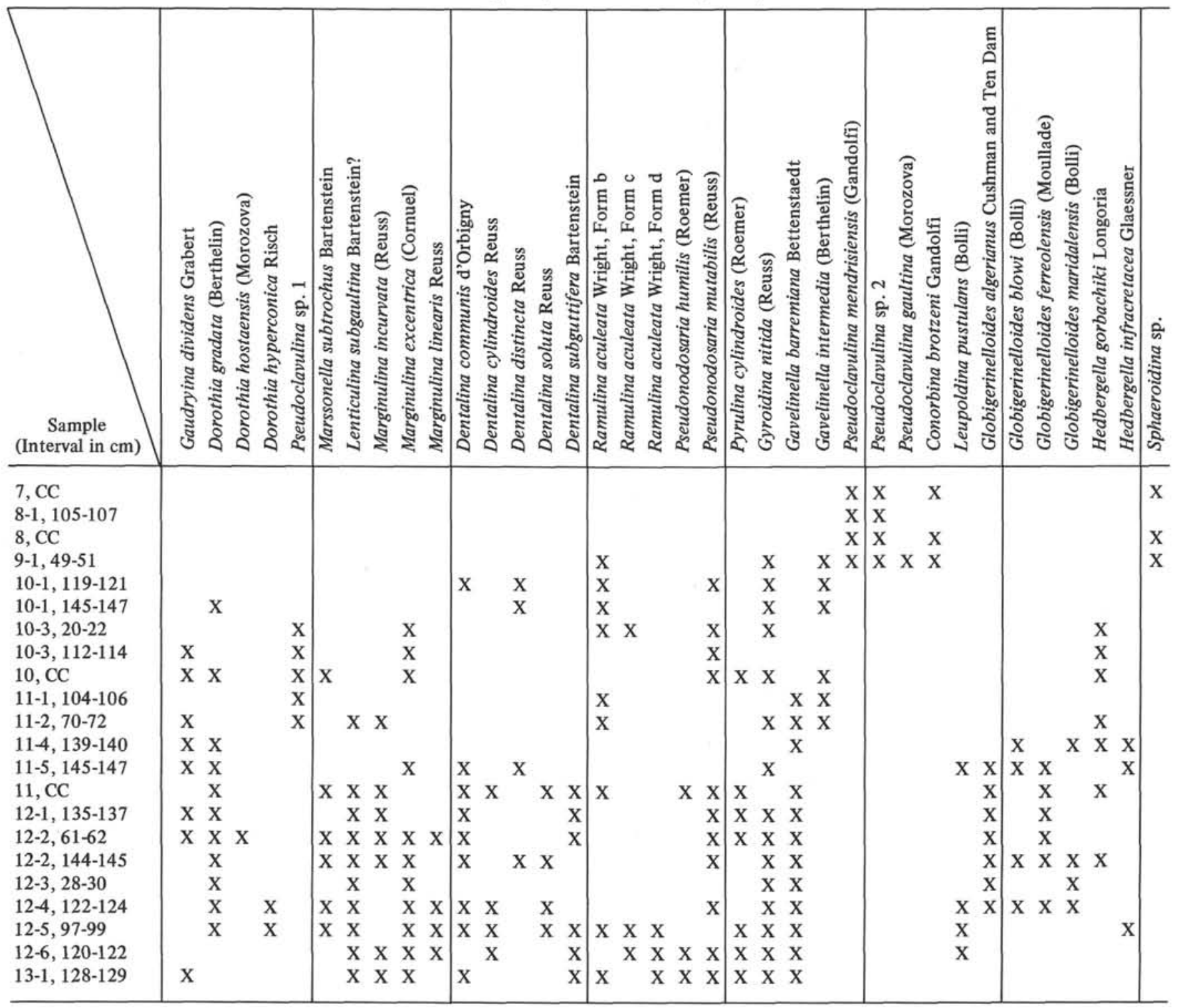

(Grzybowski), Rotorbinella supracretacea (Schijfsma), Semivulvulina denjata (Alth).

Inasmuch as the base of the $G$. calcarata Zone and the base of the upper Campanian are considered synchronous in this framework (Cita, 1971), the top of this zone can be carried to the $G$. calcarata appearance.

The absence of foraminifers from the basal 100 meters of this interval opens to question their inclusion in the lower Campanian. However, neither is there evidence for exclusion.

\section{Site 316}

Interval of $17-2,102-104 \mathrm{~cm}$ through $18-3$ (573.5$594.5 \mathrm{~m}$ )

Correlation: Paleocene?

Contributory Samples: 17-2, 102-104 cm; 18-3, 101$102 \mathrm{~cm} ; 18-4,128-130 \mathrm{~cm}$

Fauna: Planktonics
Globigerina pseudobulloides Plummer, Globotruncana arca (Cushman), G. linneiana (d'Orbigny), G. trinidadensis, Pseudotextularia elegans (Rzehak), Rugoglobigerina macrocephala Bronnimann?

Fauna: Benthonics

Ammobaculites expansus Plummer?, Anomalinoides midwayensis (Plummer), Aragonia trinitatensis (Cushman and Jarvis), Bulimina incisa Cushman?, Buliminella grata Parker and Bermudez, Lenticulina velascoensis White, Nonion durhami Mallory, Nuttalides florealis (White), Nuttalides texana (Cushman), Oridorsalis umbonatus (Reuss), Pseudonodosaria malpasoensis (Frizzell)?, Spiroplectammina spectabilis (Grzybowski), Vulvulina spinosa Cushman.

The top of this interval is set arbitrarily at the top of $17-2,102-104 \mathrm{~cm}$ because of Cretaceous foraminifers therein. However they are rare, weathered globotruncanids (listed above). The other samples from this inter- 
val had no globotruncanids, and only a few Tertiary planktonics. Still other samples from the interval contain a mixture of Cretaceous and Tertiary nannofossils in which the latter are rare. Apparently the interval is one of reworking, and possibly contamination as well, that could be either Cretaceous or Tertiary.

The base of the interval is taken from nannofossil information because samples from the bottom of Core 18 yielded no foraminifers.

Interval of Core 18-4 through 22 (594.5-656.5 m)

Correlation: Maestrichtian

Contributory Samples: 19-1, 20-23 cm (poor); 20-4, $42-44 \mathrm{~cm} ; 20$, CC; $21-1,132-134 \mathrm{~cm} ; 21-4,112-114 \mathrm{~cm}$

Fauna: Planktonics

Globotruncana aegyptiaca Nakkady, G. arca (Cushman), G. contusa (Cushman), G. falsostuarti Sigal, G. elevata (Brotzen), G. fornicata Plummer, G. gagnebini Tilev?, G. gansseri Bolli, $G$. lapparenti Brotzen, $G$. linneiana (d'Orbigny), G. stuartiformis Dalbiez, Pseudoguembelina excolata (Cushman), Pseudotextularia deformis (Kikoine), P. elegans (Rzehak).

Fauna: Benthonics

Bulimina velascoensis (Cushman), Lenticulina velascoensis (Cushman), Marssonella sp., Nodosarella cf. $N$. coalinguaensis Cushman and Church, Nuttalides florealis (White), N. texana (Cushman), Vulvulina spinosa Cushman.

Samples from this interval contain mixed faunas in which contaminants could not be separated from reworked specimens with confidence. Core 21 appears to represent the $G$. gansseri Zone, but 19 and 20 are mixed and 22 yielded no material.

Interval of $23-1,138-140 \mathrm{~cm}$ through $27-4,133-135 \mathrm{~cm}$ (667.38-747.85 m)

Correlation: Upper Campanian, Globotruncana calcarata Zone

Contributory Samples: $23-1,138-140 \mathrm{~cm} ; 23-2,17-19$ cm; 23-4, 148-150 cm; 27-3, 67-69 cm; 27-4, 133-135 cm

Fauna: Planktonics

Globotruncana arca (Cushman), G. calcarata Cushman, G. elevata (Brotzen), G. fornicata Plummer, G. lapparenti Brotzen, G. rosetta (Carsey), G. stuartiformis Dalbiez, G. ventricosa White, Heterohelix striata (Ehrenberg), Planoglobulina multicamerata de Klasz, Pseudoguembelina costulata (Cushman), Pseudotextularia elegans (Rzehak), Rugoglobigerina rugosa (Plummer).

Fauna: Benthonics

Aragonia trinitatensis (Cushman and Church), Reussella szajnochae (Grzybowski), Vulvulina spinosa Cushman.

Globotruncana calcarata was first encountered in 23-1, $138-140 \mathrm{~cm}$. As noted in the discussion of the form under $315 \mathrm{~A}$, it is employed to define the upper Campanian. In this case, however, there is an uncored interval of 9.5 meters between Core 23 and Core 22, and the boundary may lie anywhere in the interval. Also there is no foraminiferal material from Cores 24,25 , and 26 , but $G$. calcarata is relatively common in $27-3,67-69 \mathrm{~cm}$ and 27 . $4,133-135 \mathrm{~cm}$, providing adequate evidence of first appearance.

Interval of base of Sample 27-4, 133-135 cm to total depth (747.85-837.0 m)

Correlation: Lower Campanian, Globotruncana elevata Zone?
Contributory Sample: 30, CC

Fauna: Planktonics

None.

Fauna: Benthonics

Aragonia trinitatensis (Cushman and Church), Reussella szajnochae (Grzybowski), Spiroplectammina sp., unidentified robust discorbids (contaminants).

Rocks of this interval are coarse-grained volcanogenic clastics, from which only Sample 30, CC yielded a sparse and restricted assemblage of benthonics, notable only in the exceptional size and relative abundance of $R$. szajnochae. Assignment to lower Campanian is based solely on position with respect to Core 27 and the overlying appearance of $G$. calcarata.

\section{Manihiki Plateau}

Hole 317A m)

Interval of base of Core 2 through Core 3 (563.5-573.0

Correlations: Maestrichtian, mixed

Contributory Samples: 2, CC; 3-1, 96-98 cm; 3-2, 40$42 \mathrm{~cm} ; 3-4,8-10 \mathrm{~cm} ; 3, \mathrm{CC}$

Fauna: Planktonics

Globotruncana arca (Cushman), G. contusa (Cushman), G. fornicata Plummer, G. gansseri Bolli, G. linneiana (d'Orbigny), G. mayaroensis Bolli, G. stuarti (de Lapparent), G. stuartiformis Dalbiez, Gublerina cuvillieri Kikoine, Heterohelix punctulata (Cushman), Planoglobulina multicamerata de Klasz, P. carseyae (Plummer), Pseudoguembelina excolata (Cushman), P. elegans (Rzehak), Racemiguembelina fructicosa (Egger), Rugoglobigerina rotundata Bronnimann, Rugotruncana subcircumnodifer (Gandolfi), Rugotruncana subpennyi (Gandolfi).

Fauna: Benthonics

Aragonia trinitatensis (Cushman and Jarvis), Dorothia trochoides (Marsson), Verneuilina cretacea Karrer, Vulvulina spinosa Cushman.

Cretaceous foraminifers were encountered first in Sample 2, CC, which yielded a mixed Maestrichtian fauna. Eocene forms occur in Core 2, but it could have come from far uphole inasmuch as the core followed a long interval of washing down. The Cretaceous is associated with a drilling break.

Samples from Core 3 contain the nominate species from all three foraminiferal zones of the Maestrichtian, suggesting slow and unstable sedimentation.

Interval of Cores 4, 5, and $6(573.0-592.0 \mathrm{~m})$

Correlations: Campanian

Contributory Samples: 4, CC; 5-1, 126-128 cm; 5, CC; 6-2, 4-6 cm

Fauna: Planktonics

None.

Fauna: Benthonics

Aragonia trinitatensis (Cushman and Jarvis), Dorothia trochoides (Marsson), Gaudryina sp., Gyroidina globosa (Hagenow), Gyroidina nitida (Reuss), Marssonella sp., Nuttalides florealis (White), Pleurostomella subnodosa Reuss, Pullenia quinqueloba Reuss, Rotorbinella supracretacea (Schijfsma), Stensioina excolata (Cushman), Verneuilina cretacea Karrer, Vulvulina spinosa Cushman? 
Cores 4,5 , and 6 are composed of dark clays and clayey chalk that yield tiny residues. When present, foraminifers are small, recrystallized benthonics that may misrepresent both age and environment.

The fauna of this interval contains neither planktonics nor benthonics of restricted range. However, it is suggestive of Senonian in a broad sense and, by position beneath the Maestrichtian, may be suggested as Campanian.

Interval of Cores 7, 8, and 9 (592.0-620.5 m)

Correlation: Middle-upper Albian

Contributory Samples: 7, CC; 8-1, 105-107 cm, 8, CC; 9-1, 49-51 cm

Fauna: Planktonics

Hedbergella simplex (Morrow) (one specimen), Sphaeroidina $\mathrm{sp}$.

Fauna: Benthonics

Arenobulimina preslii (Reuss), Conorbina brotzeni (Gandolfi, Dorothia hostaensis (Morozova), Gavelinella intermedia (Berthelin), Gyroidina nitida (Reuss), Lenticulina gevini Moullade, L. acuta Reuss?, Nodosaria obscura Reuss, Ramulina aculeata Wright Form b Bartenstein, Pleurostomella subnodosa Reuss, Pseudoclavulina sp. 2, P. mendrisiensis (Gandolfi), P. gaultina (Morozova), Verneuilina sp.

The verneuilinids dominate the skimpy material. They bring to mind some of Gandolfi's (1942) forms from the Scaglia Variegatta and Bianca and, particularly, Scheibnerová's (1974) fauna from Leg 27, which is Albian. C. brotzeni and $G$. intermedia indicate Albian, although the latter continues into the lower Cenomanian.

The top of this interval is questionable because one sample, 7-1, 7-9 cm, contains a sparse Santonian fauna unlike anything else in Hole $317 \mathrm{~A}$. One to three specimens of several neritic species from Texas suggest contamination in laboratory treatment. Were it not for the fact that nannofossils also indicate Santonian for the upper part of Core 7, the sample would be rejected entirely.

The base of the interval is arbitrarily set at the base of Core 9, although it could be anywhere between 9-1, 49$51 \mathrm{~cm}$ and 10-1, 145-147 cm.

Beginning with this interval, selected species are presented in a distribution chart (Table 1).

Interval of $10-1,0 \mathrm{~cm}$ through $10-2,150 \mathrm{~cm}(620.5-$ $623.5 \mathrm{~m}$ )

Correlation: Middle Albian

Contributory Samples: 10-1, 119-120 cm; 10-1, 145$147 \mathrm{~cm}$

Fauna: Planktonics

Rare, fragmentary.

Fauna: Benthonics

Conorbina brotzeni Gandolfi, Dentalina communis d'Orbigny, $D$. distincta Reuss, $D$. soluta Reuss, Dorothia gradata (Berthelin), D. hostaensis (Morozova), D. hyperconica Risch, Gavelinella intermedia (Berthelin), Gyroidina nitida (Reuss), Lenticulina acuta (Reuss), Pseudonodosaria mutabilis (Reuss), Spiroplectinata sp.

This fauna differs from that of the previous interval in its lack of the distinctive verneuilinids and presence of large lagenids. Presumably, this is a reflection of environment rather than age, considering the change in lithology from dark clays of the previous interval, to limestones of this interval.

Interval of $10-3,20-22 \mathrm{~cm}$ through $11-2,70-72 \mathrm{~cm}$ (622.70-632.22 m)

Correlation: Aptian-Albian, Ticinella roberti-Hedbergella trocoidea zones

Contributory Samples: 10-3, 20-22 cm, 10-3, 112-114 $\mathrm{cm}, 10, \mathrm{CC}, 11-1,104-106 \mathrm{~cm}, 11-2,70-72 \mathrm{~cm}$

Fauna: Planktonics

Hedbergella gorbachiki Longoria, $H$. infracretacea Glaessner.

Fauna: Benthonics

Dentalina communis d'Orbigny, Dorothia gradata (Berthelin), D. hostaensis (Morozova), Gaudryina dividens Grabert, Gavelinella barremiana Bettenstaedt, $G$. intermedia (Berthelin), Gyroidina nitida (Reuss), $L$. subgaultina Bartenstein, Marginulina exocentrica (Cornuel), $M$. incurvata (Reuss), Marssonella subtrochus Bartenstein, ?Osangularia utaturensis (Sastri and Sastri), Pseudoclavulina sp. 1, Pseudonodosaria humilis (Roemer), P. mutabilis (Reuss), Pyrulina cylindroides (Roemer), Ramulina aculeata Wright Form b Bartenstein, Bettenstaedt, and Bolli, Saracenaria spinosa (Eichenberg), Spiroplectinata sp.

The nature and range of $H$. gorbachiki has recently been established by Longoria (1972). The species occurs in the upper Aptian and lower Albian. Because of the presence of $G$. algerianus and $G$. ferreolensis in the interval below, the presence of $H$. gorbachiki in this interval can be associated with the Albian and uppermost Aptian part of its range, or essentially the Ticinella roberti and Hedbergella trocoidea zones. The species is common to abundant in Core 10 and occurs throughout the $G$. algerianus Zone below (see Table 1).

Interval of $11-4,139-140 \mathrm{~cm}$ through $12-3,28-30 \mathrm{~cm}$ (635.89-641.30 m)

Correlation: Middle Aptian; Globigerinelloides algerianus Zone

Contributory Samples: 11-4, 139-140 cm; 11-5, 145$147 \mathrm{~cm} ; 11, \mathrm{CC} ; 12-1,135-137 \mathrm{~cm} ; 12-2,61-62 \mathrm{~cm} ; 12-2$, $144-145 \mathrm{~cm} ; 12-3,28-30 \mathrm{~cm} ; 12-4,122-124 \mathrm{~cm} ; 12-5,97-$ $99 \mathrm{~cm} ; 12-6,120-122 \mathrm{~cm}$

Fauna: Planktonics

Globigerinelloides algerianus Cushman and Ten Dam, $G$. blowi (Bolli), G. ferreolensis (Moullade), G. maridalensis (Bolli), Hedbergella gorbachiki Longoria, $H$. infracretacea Glaessner.

Fauna: Benthonics

Dentalina communis d'Orbigny, D. cylindroides Reuss, $D$. distincta Reuss, D. soluta Reuss, D. subguttifera Bartenstein, Dorothia gradata (Berthelin), D. hostaensis (Morozova), Gaudryina dividens Grabert, Gavelinella barremiana Bettenstaedt, Gyroidina nitida (Reuss), Lenticulina acuta (Reuss), L. subgaultina Bartenstein, M. excentrica (Cornuel), $M$. incurvata Reuss), $M$. linearis Reuss, Marssonella subtrochus Bartenstein, $M$. oxycona (Reuss), Pseudonodosaria humilis (Roemer), P. mutabilis (Reuss), Pyrulina cylindroides (Roemer), Ramulina aculeata Wright Form b, R. aculeata Wright Form e, Saracenaria spinosa (Eichenberg), Tristix acutangula (Reuss).

Although Longoria (1972) has presented sound bases for distinction between Globigerinelloides barri (Bolli, 
Loeblich, and Tappan), G. ferreolensis (Moullade), and G. algerianus Cushman and Ten Dam, they are easily confused. The ranges reported have, understandably, varied (Bandy, 1967; Longoria, 1972, van Hinte, 1971). Coupling these facts with the generally poor preservation of material from this interval, it seems wise to infer a general middle Aptian correlation.

The benthonics are quite poorly preserved. This combines with a chaotic taxonomy to make identifications uncertain, and they should be regarded with question.

Interval of $12-4,122-124 \mathrm{~cm}$ through $12-6,120-122 \mathrm{~cm}$ (645.20-648.22 m)

Correlation: Lower Aptian; Leupoldina cabri Zone

Contributory Samples: $12-4,122-124 \mathrm{~cm} ; 12-5,97-99$ $\mathrm{cm} ; 12-6,120-122 \mathrm{~cm}$

Fauna: Planktonics

Globigerinelloides ferreolensis (Moullade), G. maridalensis (Bolli), Leupoldina pustulans (Bolli).

Fauna: Benthonics

Dentalina communis d'Orbigny, D. cylindroides Reuss, $D$. distincta Reuss, D. soluta Reuss, D. subguttifera Bartenstein, Dorothia gradata (Berthelin), Gavelinella barremiana Bettenstaedt, Gyroidina nitida (Reuss), Lenticulina subgaultina Bartenstein, $M$. excentrica (Cornuel), $M$. incurvata (Reuss), $M$. linearis Reuss, Marssonella subtrochus Bartenstein, Pseudonodosaria humilis (Roemer), P. mutabilis (Reuss), Pyrulina cylindroides (Roemer), Ramulina aculeata Wright Form b, $R$. aculeata Wright Form c, $R$. aculeata Wright Form d, $R$. aculeata Wright Form f, Saracenaria spinosa (Eichenberg).

The nominate species of the $L$. cabri Zone was not observed and the shorter ranging $L$. pustulans is very rare and poorly preserved.

The total range of Leupoldina pustulans is unclear from the literature (van Hinte, 1972 versus Longoria, 1972), but is much lower than some previous suggestions (Bandy, 1967). It is, however, associated with $L$. cabri, which van Hinte (1971) assigns to the lower Aptian and Longoria (1972) to the middle Aptian.

Interval of Core 13 to basalt $(647.0-896.0 \mathrm{~m})$

Correlation: Lower Aptian, ?Barremian

Contributory Samples: 13-1, 128-129 cm; 13-4, 07-09 $\mathrm{cm}$

Fauna: Planktonics

Rare, fragmentary, unidentifiable.

Fauna: Benthonics

Rare, fragmentary; see distribution chart, Table 1.

The cores contain considerable fragmentary ostracode and pelecypod material in the upper part of this interval (Cores 13-16), but yielded only rare, fragmentary, mostly benthonic foraminifers. By superposition, the succession is older than the L. cabri Zone, but provided no direct evidence of correlation.

\section{SUMMARY}

Table 2 shows the planktonic zones recognized at 315A, 316, and 317A.

At Line Islands Sites 315A and 316, the CretaceousTertiary boundary is associated with an interval of mixed Cretaceous and Tertiary species. Middle Maestrichtian forms of the $G$. gansseri Zone are prominent at
TABLE 2

Planktonic Foraminiferal Zones, Leg 33 Site 315A, 316, 317A

\begin{tabular}{|c|c|c|c|}
\hline & $315 \mathrm{~A}$ & 316 & $317 \mathrm{~A}$ \\
\hline Maestrichtian & $\begin{array}{l}G_{.}^{-} \text {gannsseri } \\
(19-2,29-30)\end{array}$ & 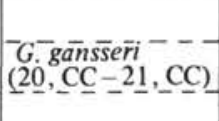 & $\begin{array}{l}\text { mixed zonal } \\
\text { species } \\
\text { (Core 3) }\end{array}$ \\
\hline \multirow{3}{*}{ Campanian } & $\begin{array}{l}\text { G. calcarata } \\
(19-3,138- \\
21-5,120)\end{array}$ & $\begin{array}{l}\text { G. calcarata } \\
(23-1,138- \\
27-4,135)\end{array}$ & \\
\hline & $\begin{array}{l}\text { G. elevata } \\
(21-5,120- \\
\text { total depth) }\end{array}$ & $\begin{array}{l}\text { G. elevata } \\
(27-4,135- \\
\text { total depth) }\end{array}$ & \\
\hline & \multirow[t]{3}{*}{ no pla } & ktonics & \\
\hline \multirow[t]{2}{*}{ Aptian } & & & $\begin{array}{l}\text { G. algerianus } \\
(11-4,139- \\
12-3,30)\end{array}$ \\
\hline & & & $\begin{array}{l}\text { L. cabri } \\
(12-4,122- \\
12-6,122)\end{array}$ \\
\hline
\end{tabular}

both locations. Samples indicate some $G$. arca Zone in $315 \mathrm{~A}$ and possibly in 316 , but no evidence of the $G$. mayaroensis Zone was observed. The G. calcarata Zone is present and sharply defined by the nominate species in relative abundance. The $G$. elevata Zone is presumed from subjacent position and a few appropriate but not exclusive forms. A definitive base of the zone, in the form of $G$. concavata, did not occur before total depth in both holes. The $G$. calcarata Zone thickens from 25 meters at $315 \mathrm{~A}$ in the north to 195 meters in 316 at the south.

Foraminiferal faunas vary sharply with lithology in Hole $317 \mathrm{~A}$, which includes a thin, uppermost chalk, a broken section of dark, barren clays and clayey chalk, an Aptian-Albian carbonate unit, and a basal volcanogenic, clastic section.

The Cretaceous-Tertiary boundary is sharp in Hole 317A. Samples from the uppermost chalk, only 9.5 meters thick, contain nominate and other elements of all three Maestrichtian planktonic stages, making it difficult to distinguish between contamination and reworking. The relatively long, dark clay unit yielded only sparse faunas of small, recrystallized benthonics. The upper part of this unit, Cores 4-6, contains undifferentiated Senonian benthonics. The lower part, Cores 7-10, contains, with the questionable exception of 7-1, Albian benthonics. Faunas of the Aptian-Albian chalks and limestones are dominated by large, diverse lagenids of poor preservation and uncertain identification. However planktonics are present, and are sporadically abundant, allowing the recognition of the Globigerinelloides algerianus Zone and the Leupoldina cabri Zone. The benthonic faunas of the dark clays resemble faunas reported from the Mediterranean and, recently, 
from Australian-Indian Ocean sites. The Aptian-Albian faunas resemble those of Trinidad and the Caribbean, but are similar also to many of Tethyan Europe.

\section{ACKNOWLEDGMENTS}

I am grateful for assistance by many individuals and institutions during this study. Drs. J.E. van Hinte of Esso Corporation, Houston, Texas, and H. Luterbacher of Esso, Begles, France, were most helpful in identification and literature search. Dr. Terry Edgar, Scripps Institute of Oceanography, San Diego, California, provided financial support for SEM illustrations; Dr. P.A. Pessagno and Tom Rothwell of the University of Texas at Dallas provided SEM time and made the SEM exposures. I am indebted to the University of Texas at Arlington for leave during the voyage of Leg 33 and am sincerely grateful to NSF and JOIDES for the opportunity to participate in the Deep Sea Drilling Project.

\section{REFERENCES}

Bandy, O.L., 1967. Cretaceous planktonic foraminiferal zonation: Micropaleontology, v. 13, p. 1-31.

Bartenstein, H., Bettenstaedt, F., and Bolli, H., 1957. Die Foraminiferen der Unterkreide von Trinidad, B.W.I.,
Erster Teil: Cuche- und Toco-Formation: Eclog. Geol. Helv., v. 50, p. 5-67.

Cita, M. B. and Gartner, S., 1971. Deep sea Upper Cretaceous from the Western North Atlantic: Proc. Plankt. Conf. II, Rome, 1970 , p. 287-319.

Gandolfi, R., 1942. Richerche micropaleontologiche e stratigrafiche sulla Scaglia e sul Flysch cretacici dei dintorni di Balerna (Canton Ticino): Riv. Ital. Paleontol., v. 20, p. 1158.

Le Calvez, Y., de Klasz, L., and Brun, L., 1971. Quelques foraminiféres d'Afrique occidentale: Rev. Espan. Micropal., v. 3, p. 305-326.

Longoria, J.F., 1972. Stratigraphic, morphologic and taxonomic studies of Aptian planktonic foraminifera: Rev. Espan. Micropal., Num. Extraord., p. 1-107.

Moullade, M., 1966. Étude stratigraphique et micropaleontologique du Cretace Inferieur de la "Fosse Vocontienne”: Doc. Lab. Geol. Fac. Sci., Lyon, no. 15, p. 1-369.

Scheibnerová, V., 1974. Aptian-Albian benthonic foraminifera from DSDP Leg 27, Sites 259, 260, and 263, eastern Indian Ocean: In Heirtzler, J., Veevers, J., et al., Initial Reports of the Deep Sea Drilling Project, Volume 27: Washington (U.S. Government Printing Office), p. 697-743.

van Hinte, J.E., 1972. The Cretaceous time scale and planktonic foraminiferal zones: Koninkl. Nederl. Akad. Wetenschap Amsterdam Proc., Ser. B, v. 75, p. 61-68. 


\section{PLATE 1}

Figures 1,2 Globigerinelloides algerianus Cushman and Ten Dam.

Sample 317A-12-2, 144-145 cm; $\times 123$.

Figure 3 Globigerinelloides ferreolensis (Moullade).

Sample 317A-12-1, 135-137 cm; $\times 123$.

Does not show as much evolution of final chambers as occurs elsewhere.

Figures 4, $5 \quad$ Globigerinelloides blowi (Bolli)

Sample 317A-12-2, 144-145 cm; $\times 123$.

Interpreted here as by Longoria (1972), not as by Moullade (1966).

Figure $6 \quad$ Globigerinelloides maridalensis (Bolli).

Sample 317A-12-4, 122-124 cm; $\times 123$.

Figures 7-9 Hedbergella gorbachiki Longoria.

Sample 317A-10-3, 20-22 cm.

7. $\times 164$.

8. $\times 205$.

$9 . \times 123$.

Figure $10 \quad$ Leupoldina pustulans (Bolli).

Sample 317A-12-5, 97-99 cm; $\times 164$.

This species is rare; poor preservation obscures secondary chamber relationships.

Figure $11 \quad$ Gaudryina dividens Grabert.

Sample 317A-11-5, 145-147 cm; $\times 82$.

Figure 12 Gaudryina dividens Grabert.

Sample 317A-11-2, 70-72 cm; $\times 82$.

This species appears to vary into forms that approach Spiroplectinata. 


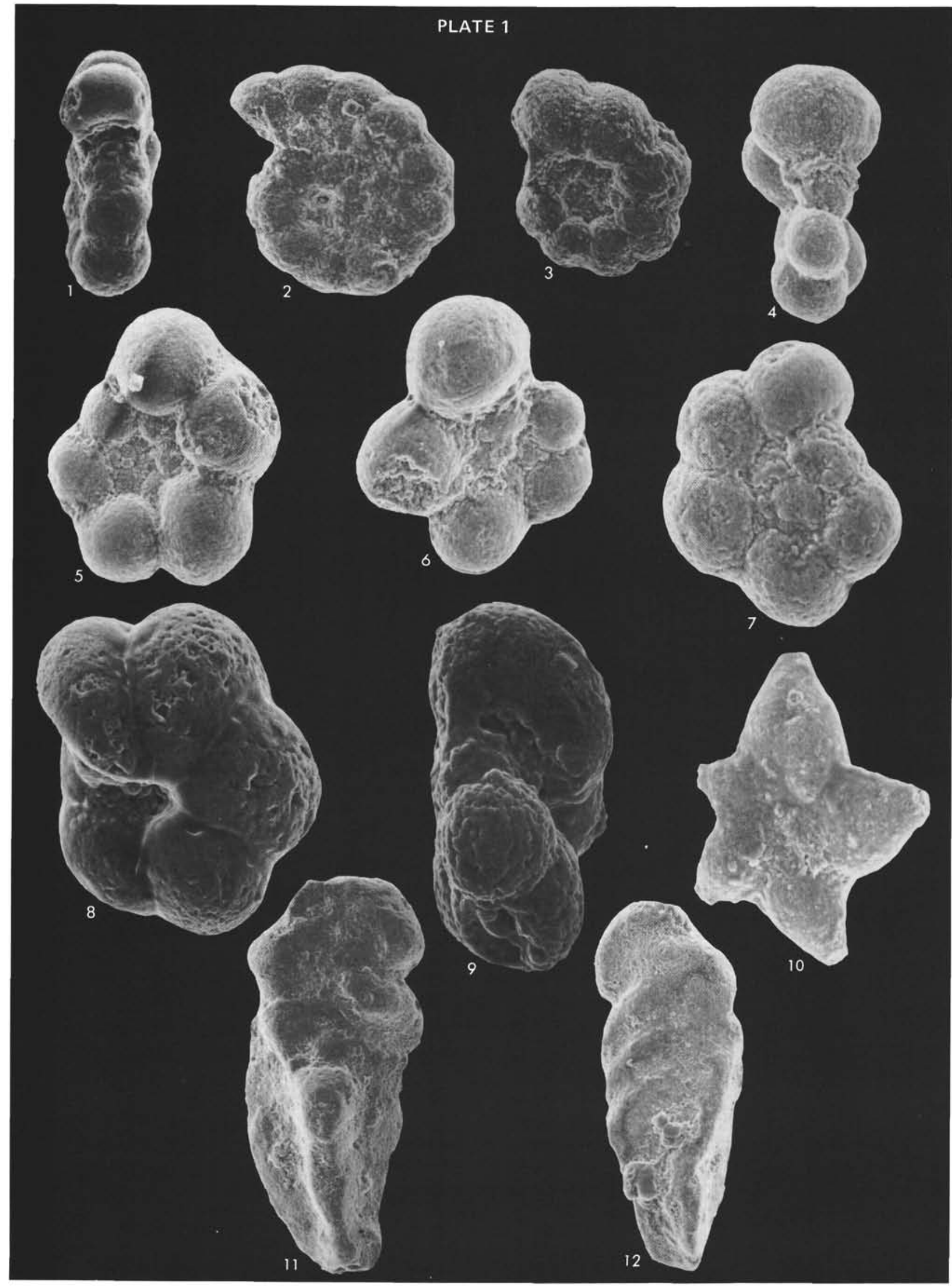


PLATE 2

Figure $1 \quad$ Spiroplectinata $\mathrm{sp}$.

Sample 317A-10-3, 20-22 cm; $\times 82$.

Figure 2 Pseudoclavulina gaultina (Morozova).

Sample 317A-9-1, 49-51 cm; $\times 82$.

Figures 3,4 Pseudoclavulina sp. 2.

Sample 317A-8-1, 105-107 cm; $\times 66$.

This form is very distinctive because of the shape of the uniserial chambers. It appears synonymous with the form that Gandolfi (1942, p. 43) identified as Pseudoclavulina eggeri in text and as Clavulina parisiensis in illustrations (1942, pl. XI, fig. 5, 6; pl. XII, fig. 3, 4), but it is neither of these. It is the form that Scheibnerova (1947, p. 722, pl. 2, fig. 58) assigned to Pseudoclavulina gabonica but it differs markedly from that species (Le Calvez, de Klasz, and Brun, 1971, p. 308, pl. I, fig. 7 and 9) in uniserial chambers.

Figure 5

Pseudoclavulina mendrisiensis (Gandolfi).

Sample 317A-10, CC; $\times 49$.

The concept herein is restricted to the terminal form of the Gandolfi (1942, p. 42) variation of the species in which the biserial stage is very suppressed, the uniserial stage is relatively short, and the chambers are more overlapping and ill defined. This concept is similar to Clavulina gabonica Le Calvez, de Klasz, and Brun (1971).

Figure $6 \quad$ Gavelinella barremiana Bettenstaedt. Sample 317A-12-2, 144-145 cm; ×164.

Figure $7 \quad$ Gavelinella barremiana Bettenstaedt. Sample 317A-12-2, 144-145 cm; ×164.

Figures 8,9 Pseudoclavulina sp. 1.

Sample 317A-11-2, 70-72 cm; $\times 49$.

This form appears inseparable from gaudryinelline accompanying forms, of which some approach Gaudryina angustata Akimez.

Figure 10 Dorothia hyperconica Risch.

Sample 317A-12-4, 28-30 cm; $\times 82$. 


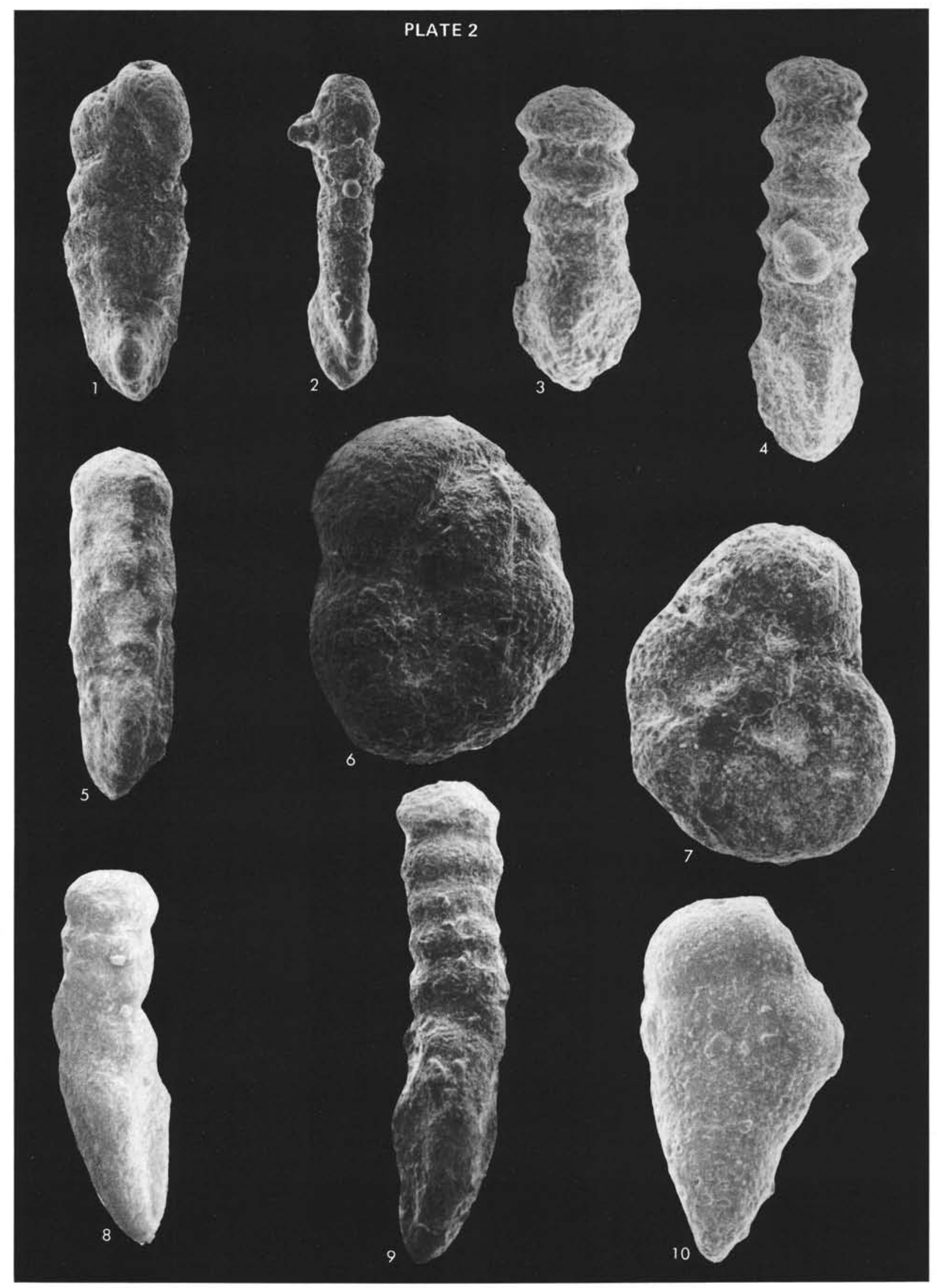




\section{PLATE 3}

Figure 1 Dorothia gradata (Berthelin).

Sample $317 \mathrm{~A}-12-1,135-137 \mathrm{~cm} ; \times 82$.

Figure 2 Marssonella subtrochus Bartenstein. Sample 317A-12-4, 122-124 cm; $\times 123$.

Figure 3 Dentalina cylindroides Reuss. Sample 317A-11, CC; $\times 62$.

Figure $4 \quad$ Lenticulina subgaultina Bartenstein?. Sample 317A-12-1, 135-137 cm; $\times 82$.

Figures 5-7 Marginulina excentrica (Corneul).

Sample 317A-12-2, 61-62 cm; $\times 82$.

This form has many short, strongly oblique chambers in the uncoiled portion, but they are only faintly preserved in Hole 317A material. With inclusion of $M$. prima (d'Orbigny) as a junior synonym (Bartenstein, 1966, p. 149), M. excentrica varies from strongly astacoline to strongly marginuline.

Figure $8 \quad$ Marginulina incurvata (Reuss).

Sample $317 \mathrm{~A}-12-2,144-145 \mathrm{~cm} ; \times 82$.

Figure $9 \quad$ Marginulina linearis Reuss.

Sample 317 A-12-6, 120-122 cm; $\times 82$. 


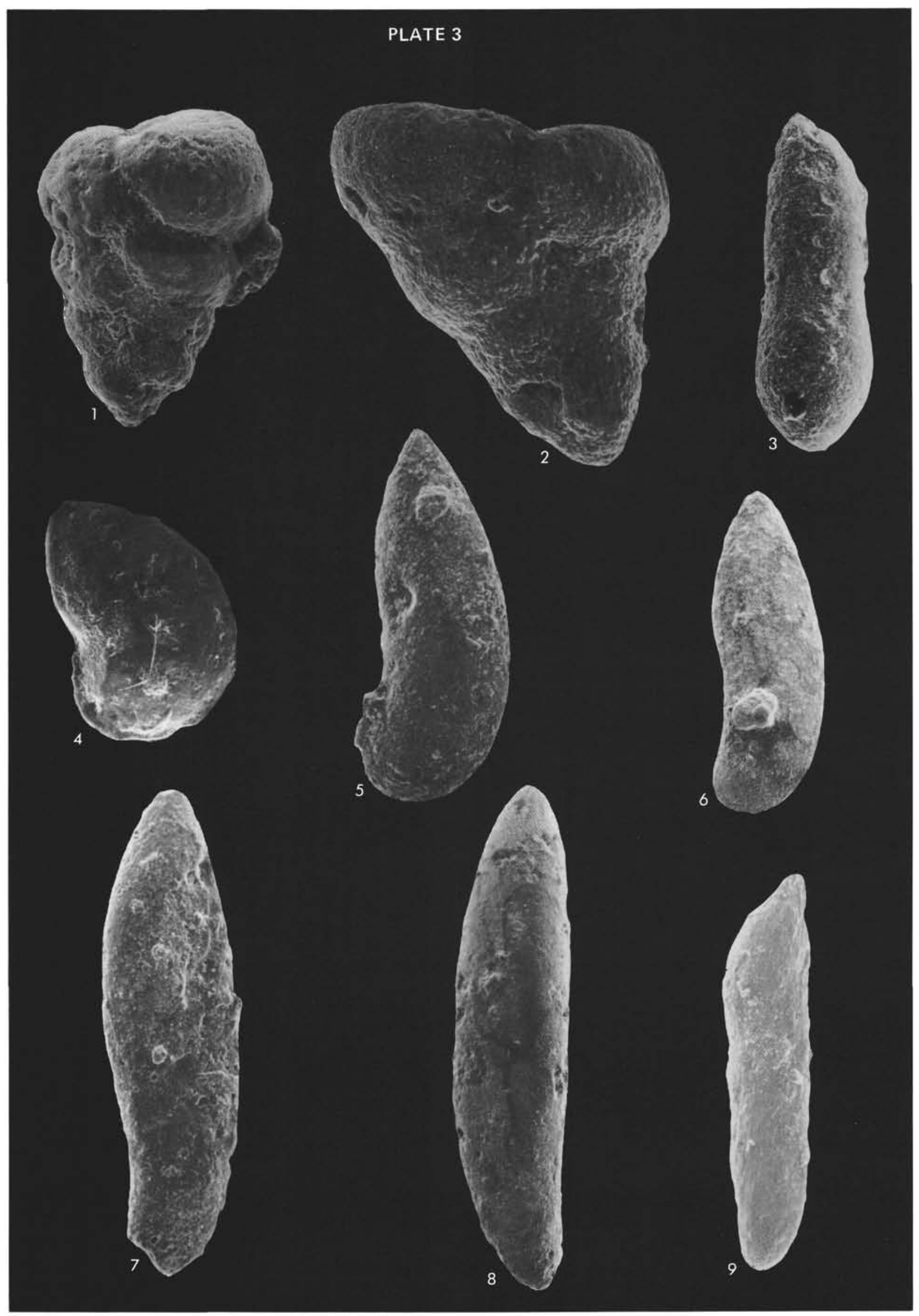

